\title{
Analyze Structure, Conduct, and Performance (SCP) of Maize Markets in Case of Alefa District Northwestern Ethiopia
}

\author{
Abera Ayalew $^{1 *} \quad$ Fentahun Tesafa $^{2}$ Zewdu Berhanie ${ }^{2}$ \\ 1.Department of Agricultural Economics, Woldia University, Woldia, Ethiopia \\ 2.Department of Agricultural Economics, Bahir dar University, Bahir dar, Ethiopia
}

\begin{abstract}
This study examined the major market channels, and evaluate the market margins for key maize marketing channels in Alefa District, Central Gondar Zone of Amhara Regional State. Both primary and secondary data sources for the study were collected. Primary data were collected through personal interviews from a total of 198 producers and 34 traders. Descriptive statistics was employed to describe the socio-economic characteristics of farm households, and to analyze market related data collected from maize traders. The results show that wholesalers and rural assemblers are the most important buyers of maize from producers, accounting for 44 and $36.35 \%$ respectively. Market concentration ratio of $74.07 \%$ indicates that the maize market in the study area is characterized as oligopolistic. The result of the study also showed that, maize average production and yield were 18.03 quintals per household and 34.37 quintals per hectare, respectively. The major constraints for maize production and marketing of households in the study area include high price of fertilizers, timely availability of improved seeds, large number of unlicensed traders in the markets, climate change (occurrence of drought, pest/diseases), availability of credit access and non-transparent taxation system. The opportunities comprises presence of potential farmers' cooperatives to supply fertilizer and improved maize seeds, other farm inputs, and reliable and timely market information sourced from government department; maize productive potential of the area; improved trends of quality of maize; and creating demand for other crops. Finally the study recommends the need to strengthen and promote cooperatives to further exploit their economies of scale through diversifying their intermediary services both in the input and output markets of maize, market information and extension systems. Keywords: Concentration ratio, Cooperatives, Maize, Oligopolistic.
\end{abstract}

DOI: $10.7176 / \mathrm{JMCR} / 70-01$

Publication date:August $31^{\text {st }} 2020$

\section{INTRODUCTION}

In 2017, global maize production added up to 1.04 billion tons, of which close to 15 percent were traded on international markets. Over the last few years the global stock-to-use ratio was around 25 percent which had a stabilizing effect on international maize prices (FAO-AMIS, 2017).

Maize is the most widely-grown staple food crop in sub-Saharan Africa (SSA) occupying more than 33 million ha each year. The crop covers nearly $17 \%$ of the estimated 200 million ha cultivated land in Sub-Saharan Africa, and is produced in diverse production environments and consumed by people with varying food preferences and socio-economic backgrounds. Ethiopia is among the top 20 countries $^{1}$ which are accountable for $96 \%$ of the total maize production in SSA (FAOSTAT, 2015).

Maize arrived in Ethiopia in the late seventeenth century (Huffnagel, 1961). Compared to other cereals, though it is a late comer to the country, currently it accounts for the largest share of production by volume and is produced by more farmers than any other cereals (Chamberlin and Schmidt, 2012). In the 2015/16 production season, 2.11 Million hectares of land was covered by maize in the country from which 71.51 Million qt of output were produced by 9.55 Million holders (CSA, 2016). The productivity of maize has reached to $34.29 \mathrm{qt} / \mathrm{ha}$ in $2014 / 15$ production season by achieving a tremendous growth compared with a $21.87 \mathrm{qt} / \mathrm{ha}$ in $2005 / 06$ production season (CSA, 2015a).

In Ethiopia small holders cultivate maize mainly as a subsistence crop rather than a commercial crop while the large modern farms mainly produce for the market. In 2004/5 national survey of consumption expenditure indicated that maize accounted for $16.7 \%$ of the national calorie intake followed by sorghum (14.1\%) and wheat (12.6\%) among the major cereals (Guush Berhane et al., 2011). In terms of area coverage, it is the second most important commodity following teff.

Alefa district is endowed with favorable climatic and natural resource conditions that can grow diverse annual and perennial crops required for household consumption and for the market. Despite the fact that, the district produces agricultural products based on rain-fed (OAWARD, 2017). Even though the major cereal crops grown in the district include maize, teff, finger millet, barley, and wheat, previously there is no such study trying to look marketing chains of maize crop, especially considering socio-economic characteristics of traders and smallholder

\footnotetext{
${ }^{1}$ These are South Africa, Nigeria, Ethiopia, Tanzania, Malawi, Kenya, Zambia, Uganda, Ghana, Mozambique, Cameroon, Mali, Burkina Faso, Benin, DRC, Angola, Zimbabwe, Togo, and Cote d'Ivoire
} 
farmers. This makes the undertaking of market structure, conduct and performance analysis of maize in the district imperative. This study is therefore designed to address the information gaps on the subject, contribute to proper understanding of the challenges, and support in developing improved market development strategies to the benefit of smallholder farmers, traders, and other market participants.

\section{RESEARCH METHODOLOGY}

\subsection{Description of the study area}

This study was conducted in Alefa district, which is located in Central Gondar Zone, Amhara Regional state of Ethiopia. The district is bordered on the southwest by the Agew Awi Zone, on the west by Qwara, on the north by Takusa, on the east by Lake Tana and on the southeast by West Gojjam Zone. The administrative center of the district is Shawra, which is located $88 \mathrm{~km}$ from east of Bahir dar and $142 \mathrm{~km}$ north of Gonder town. The district is subdivided into 25 rural kebeles and one sub-urban kebele administration (OAWARD, 2017).

The agro -ecological condition of Alefa district is suitable for the production of maize and grain legumes. About $45 \%$ of land area in the district lies in mid-highland (Woinadega) whereas $55 \%$ is mid-lowland (Kolla). It lies between $11045^{\prime}$ and 12030' $\mathrm{N}$ latitude, and $37010^{\prime}$ and $36030^{\prime} \mathrm{E}$ longitudes coordinate, respectively, and at an altitude that ranges from 750 to 2250 meter above sea level. Its temperature ranges from $25-38^{\circ} \mathrm{C}$. The district has minimodal rainfall distribution, which extends from June to end of August with average annual rainfall reaching 900-1400 $\mathrm{mm}$. The district has larger proportion for areas with red soil whereas brown and black soils also constitute some proportions (OAWARD, 2017).

Major constraints of the farming systems in the district include low soil fertility, crop pests and diseases, shortage of improved varieties, inappropriate cropping practice and land preparation. Poor market infrastructures also affect crop production in the area. Similarly, animal diseases and parasites, low performance of local breeds, and short supply of improved forage seed are major constraints for livestock production.

\subsection{Types, Sources and Methods of data collection}

To address the objective of the study, both qualitative and quantitative cross sectional data were collected from primary and secondary sources. Primary data were collected using structured questionnaires from maize traders and small holder farmers; and secondary data were collected by reviewing different published and unpublished documents such as Alefa District Agriculture and Rural Development Office, office of small scale trade and industry, each kebele office, international organizations (such as FAO, WB, etc) and websites to generate data on maize production and marketing. Furthermore, from these secondary sources data on prices, output, number of licensed maize traders, maize marketing system, legal requirement to enter grain trading business and data on other socio- economic variables are taken.

\subsection{Sampling Procedure and Sample Size}

The sites for the trader surveys were market towns in which a good sample of maize traders existed. On the basis of flow of maize, four markets (Shahura, Atedemariam, Dengelber and Zabza) were selected as the main maize marketing sites for the study area. Wholesalers, retailers, urban assemblers, and rural assemblers, were chosen randomly from specified markets by classifying traders in to four strata. Based on volume of transaction a total of 34 maize traders were selected randomly to obtain information related to market channel. Among which, 8 wholesalers, 14 retailers, 7 rural assemblers, and 5 urban assemblers were included.

Table 1: Sample distribution of maize traders across selected markets in Alefa district

\begin{tabular}{|c|c|c|c|c|c|}
\hline Traders & \multicolumn{4}{|c|}{ Markets of Alefa district } & Total \\
\hline & Shahura & Atedemariam & Dengelber & Zabza & \\
\hline Wholesalers & 3 & 2 & 2 & 1 & 8 \\
\hline Retailers & 3 & 4 & 2 & 5 & 14 \\
\hline Urban assemblers & 2 & 2 & 1 & --- & 5 \\
\hline Rural assemblers & 3 & 1 & 3 & --- & 7 \\
\hline Total & 11 & 9 & 8 & 6 & 34 \\
\hline
\end{tabular}

Source: Survey result (2017).

\subsection{Methods of data analysis}

The descriptive statistics (such as percentages, pie chart, mean, minimum, and maximum) were used in the process of examining and describing structure, conduct and performance of maize market, farm households and traders characteristics, and major constraints and opportunities of maize production and marketing. The following are indicators estimated using the descriptive statistics.

Market concentration: refers to the number and size distribution of sellers and buyers in the market, the firm's objectives, barriers to entry, economies of scale, and assumptions about rival firm's behaviors are important in determining the degree of concentration and behaviors and performance (Baldwin and Scott, 2013). According to 
Kohls and Uhl (2002), a four largest firm's concentration ratio of 50\% or more is considered as a strongly oligopolistic market, while a concentration ratio of $33-50 \%$ considered a weak oligopoly, and less than $33 \%$ is competitive market.

In general the greater the degree of concentration, the greater will be the possibility of non-competitive behavior, such as collusion, existing in the market. The concentration ratio will be calculated using the following formula.

$$
\mathrm{MS}_{\mathrm{i}}=\frac{\mathrm{V}_{\mathrm{i}}}{\sum \mathrm{V}_{\mathrm{i}}}
$$

Where $\mathrm{MS}_{\mathrm{i}}-$ Market share of buyer $\mathrm{i}$ in percent

$\mathrm{Vi}$ - Amount of product handled by buyer i per week (quintal)

$\sum \mathrm{Vi}$ - Total amount of product handled by buyer i per week (quintal)

$\mathrm{C}=\sum_{i=1}^{r} \mathrm{Si}$.

Where C-Concentration ratio for the largest firms

Si- Percentage share of $i^{\text {th }}$ firms

$\mathrm{r}$ - Number of largest firms for which the ratio is going to be calculated

Marketing margin- is the difference between the price received by producers and that paid by consumers (Tomek and Kaiser, 2014). According to Emam (2011) marketing margins should be understood as the gross marketing margins. He advises marketing researchers to emphasize on gross marketing margins in reporting their findings.

Large gross margins may not express high profit; this is because size of marketing margins largely depends upon a combination of the quality and quantity of marketing services, and the efficiency with which they are undertaken and priced. The quality and quantity of marketing services depends on supply and demand of marketing services and/or the degree of competition in the market place. Therefore, in using market margin analyses to assess the economic performance of markets, it is always preferable to analyze them into their cost and return elements (Kalule and Kyanjo, 2013).

Onono, Amimo et al. (2015) advises that precise marketing costs are frequently difficult to determine in many agricultural marketing chains. The reasons are that these costs are often both cash costs and imputed costs, the gross and not the net marketing margin is advised to be calculated.

After adjusting average variable and fixed costs, gross profit and marketing margins of traders, total gross marketing margin (TGMM) and producers' gross marketing margin (GMMp) were calculated for analyzing performance of maize market in the district.

The producers' share is the commonly employed ratio calculated mathematically as, the ratio of producers' price (ex-vessel) to consumers' price (retail). Mathematically, producers' share can be expressed as:

$\mathrm{PS}=\frac{\mathrm{P}_{\mathrm{x}}}{\mathrm{P}_{\mathrm{r}}}=1-\frac{\mathrm{MM}}{\mathrm{P}_{\mathrm{r}}}$

Where: PS = Producers' share

$\mathrm{Px}=$ Producers' price of maize

$\operatorname{Pr}=$ consumer price of maize (Retail price)

$\mathrm{MM}=$ marketing margin

The above equation tells us that a higher marketing margin diminishes producers' share and vice versa. It also provides an indication of welfare distribution among production and marketing agents.

$$
T G M M=\frac{\text { consumer } \text { price }- \text { producers ' price }}{\text { Consumer price }} X 100
$$

$$
\begin{aligned}
& \operatorname{GMM} p=\frac{\text { Price paid by consumer }- \text { Marketing gross margin }}{\text { Price paid by the consumer }} \mathrm{X} 100 \\
& \text { Where GMMp - Producers' participation (farmers' portion) }
\end{aligned}
$$

\section{RESULTS AND DISCUSSION}

\subsection{Socio-economic characteristics of maize traders}

3.1.1. Demographic characteristics of maize traders

The demographic characteristics of traders indicate that average age of traders were 38.68 years. The marital status of traders indicated that all traders interviewed were married. In terms of educational status of maize traders in the study area, about $26.4 \%$ of the sampled traders were completed primary school whereas $64.7 \%$ of traders completed secondary and high school level education. The remaining $8.9 \%$ of the traders attended college level education. Respondents' average years of maize trade experience was 11.21 years. The study also revealed that among the sampled traders, none of the traders in any of the markets specialized in the maize trade alone. 
Table 2: Demographic characteristics of sampled maize traders $(n=34)$

\begin{tabular}{clll}
\hline Variables & Items & Number of traders & Percent \\
\hline Sex & Male & 32 & 94.1 \\
& Female & 2 & 5.9 \\
Marital status & Married & 34 & 100 \\
Educational level & Primary school & 9 & 26.4 \\
& Secondary and high school & 22 & 64.7 \\
& College education & 3 & 8.9 \\
\hline Average age of maize traders & 38.68 years & \\
Average experience in maize trading & 11.21 years & \\
\hline
\end{tabular}

Source: Survey result (2017).

\subsubsection{Traders resource ownership}

Physical assets: The survey indicates that $26.47 \%$ of the sampled traders reported that they had a separate place of storage while $73.53 \%$ of them indicated that they had residence store. Trader's average storage holding capacity for separate stores was 197 quintals whereas the residence store was 38 quintals.

Similarly, the entire sample traders had their own mobile phone and had no land line telephone. In terms of value, trucks are clearly the most important. However, ownership of truck (vehicles) is highly concentrated with a small proportion of surveyed traders. Thus, only $29.41 \%$ of traders had truck. In terms of equipment, $100 \%$ of the surveyed traders own weighing scale. For transporting maize from collection point to store and market, only $14.7 \%$ of traders had hand pooled cart.

Table 3: Distribution of sampled traders by physical asset ownership

\begin{tabular}{lll}
\hline Descriptions & Frequency & Percent \\
\hline Separate store & 9 & 26.47 \\
Separate store capacity(average, qt) & $197 \mathrm{qt}$ & -- \\
Residence store & 25 & 73.53 \\
Residence store capacity(average, qt) & $38 \mathrm{qt}$ & -- \\
Mobile telephone & 34 & 100 \\
Land line telephone & -- & -- \\
Weighing scale & 34 & 100 \\
Truck & 10 & 29.41 \\
Hand pool cart & 5 & 14.7 \\
\hline
\end{tabular}

Source: Survey result (2017).

Financial capital of sample maize traders: The initial and current working capital could be one of the indicators of the financial position of a given firm though it may not necessarily show the financial progress of the firm. The average initial working capital was estimated to be Birr 13,308.82. Moreover, as it was indicated in Table 4, the current working capital of maize traders was greater than their initial working capital. With regard to the sources of working capital, $61.8 \%, 5.8 \%, 20.6 \%, 5.8 \%$ and $5.8 \%$ of maize traders in the markets reported that their source of working capital was own saving, Bank loan, MFI, Trader associations and other sources respectively.

Table 4: Distribution of sampled traders by financial asset ownership and sources

\begin{tabular}{llll}
\hline Descriptions & Minimum & Maximum & Mean \\
\hline Initial working capital (birr) & $2,000.00$ & $60,000.00$ & $13,308.82$ \\
Current working capital (birr) & $10,000.00$ & $500,000.00$ & $108,676.47$ \\
\hline Source of current working capital & $\mathrm{N}$ & $\%$ & \\
Own saving & 21 & 61.8 & \\
Bank loan & 2 & 5.8 & \\
MFI & 7 & 20.6 & \\
Trader Associations & 2 & 5.8 & \\
Others & 2 & 5.8 & \\
\hline
\end{tabular}

Source: Survey result (2017).

\subsection{Analysis of structure, conduct and performance of maize market}

\subsubsection{Structure of maize market}

Wendmagegn Belete (2014) found that the structure of the coffee market was calculated in terms of the market concentration, barrier to entry (licensing procedure, lack of capital and know how), and the degree of transparency. For this study, maize market structure was evaluated using market concentration ratio, degree of transparency (market information) and barriers to entry (licensing procedure and lack of capital) to evaluate the structure of the 
maize market.

\section{Measure of market concentration ratio}

For these study major actors which participate in maize buying and selling activity was taken for considering market structure. The primary maize market is characterized by un-concentrated suppliers due to a very large number of farmers, where no producer affects the functioning of other producers. Calculation of the concentration ratio by considering an average volume of maize handled by largest wholesalers per week in peak production season basing the four firm criteria indicated the existence of oligopoly market power. Four firms control $74.07 \%$ of the total amount of maize sold in market during harvesting/peak production season. Hence, it is concluded that maize market at district level is strong oligopoly and non-competitive.

Table 5: Maize traders' concentration ratio in Alefa district.

\begin{tabular}{lll}
\hline Traders & $\begin{array}{l}\text { Total volume of maize } \\
\text { handled per week (quintal) }\end{array}$ & $\%$ share of purchase \\
\hline 1 & 50 & 6.17 \\
2 & 70 & 8.64 \\
3 & 90 & 11.11 \\
4 & 120 & 14.81 \\
5 & 130 & 16.05 \\
6 & 150 & 18.52 \\
7 & 200 & 24.69 \\
\hline Total & 810 & \\
\hline
\end{tabular}

Source: Survey result (2017).

As indicated on Table 5 maize markets were strongly oligopolistic in the hands of few maize traders. The CR4 measures of market concentration ratio showed that the top four or $11.76 \%$ of traders controlled $74.07 \%$ of the total volume of maize sold in 2017. This indicates that there is market imperfection because few traders seem to have monopolized the maize market. Similarly, Sultan Usman (2016) for the study of analysis of wheat value chain; the case of sinana district four firms' control $88.7 \%$ of the total amount of wheat sold in market. Hence, it is concluded that wheat market at district level is non-competitive.

\section{Barriers to entry}

The entry conditions in to the market includes licensing procedure, lack of capital and knowhow which reflect the competitive relationships between existing traders and potential entrants. If the barriers to entry are low, new traders can easily enter into maize markets and compete with established traders.

Licensing: Licensing was also mentioned by the traders as an entry barrier because it requires high minimum capital. According to the rules and regulations of Trade and Industry in the country, licensing is imperative to enter into grain trading but there is no strong regulatory action that controls non-licensed market participant at kebele level and small towns in the district. Even though $85.3 \%$ of the sampled traders reported that the procedure to get license is somewhat simple, the requirement of having appropriate facilities such as minimum capital, weighting scale, store, etc. were the major binding factors for maize traders as these requires large capital.

Capital: According to the survey result, about $70.6 \%$ of the sample traders have reported that shortage of capital as an important problem to enter in to maize trading. In addition, the sample traders reported that lack of access to credit has been the single most critical constraint in the start-up and expansion phases. About $61.8 \%$ and $11.6 \%$ of sample traders were using their own capital and borrowing from trader association and relatives/family respectively. The rest 26.4 percent of traders (mainly wholesalers) had access to formal financial sources from Banks and MFI to expand their trading activities. Thus, capital requirement discourage traders from expanding their scale of operation, achieving greater efficiency and engaging in the long-run storage needed. This implies that capital requirement is a major entry barrier in the maize trading in the study area.

Inability to compete with unlicensed traders: About 88.2 percent of the interviewed traders pointed out that one of their serious problem were competition with unlicensed traders in the maize market. Because of the presence of unlicensed traders in the study area an individual unable to enter and compute with unlicensed traders. This is one of the indications for the presence of imperfect competition in maize market.

Generally, problems in licensing, inadequate capital and their subsequent inability to compete with unlicensed traders are identified to be the major entry barriers to maize marketing even though there are no exit barriers. Since the market concentration ratio is high and there are entry barriers into maize market, the maize market chain has deviated from the norms of competitive market structure.

\section{Degree of market transparency}

Even though information enhances market performance by improving the knowledge of buyers and sellers concerning supply and demand, there was no organized system to provide reliable market information to all market participants in the study area. Hence, traders used different approaches to access market information. According to the survey result, about $52.9 \%, 58.8 \%$ and $55.9 \%$ of sample traders obtained information about supply, demand and price through other maize traders with the help of telephone in the market respectively. The remaining $47.1 \%$, 
$41.2 \%$ and $44.1 \%$ of traders reported that they obtained market information through brokers, face to face discussion with other traders, and personal observation. Although, Medias such as television and radio play the greatest role in provision of market information in shortest possible time over larger area of coverage, its effect in addressing grain market information to users was very limited. Despite the fact that, no trader had accessed mass Medias as an information source.

Since sources and means of obtaining information by different categories of traders varied significantly, the timeliness and quality of information obtained depends on the traders' access to market information channels and their individual judgment on the level of supply, demand and prices collected from different sources and in different times. Despite the fact that about $76.5 \%$ of traders showed their willingness to pay for the information cost provided. If there are well organized and transparent information providing centers, they still complained that, market information is one of the major problems they faced in trading maize in the study area.

3.2.2. Conduct of maize trading

Market conduct explains traders' behavior with respect to various aspects of trading strategies such as buying, selling, transport, storage, information and financial strategy. This implies analysis of human behavioral patterns that are not readily identifiable, obtainable, or quantifiable due to this traders' behavior was observed as unpredictable because their main objective is profit maximization. They may cheat price, weight scales by manipulating installations of the instrument, defaulting an agreement and any combination of these simply they sold to anybody as far as he offered better price. Although there are no agreed upon procedures for analyzing the elements of market conduct, some points are put to detect unfair price setting practices and the conditions under which such practices overcome. In this study conduct of the maize market is analyzed in terms of the producers' price setting strategy, traders' price setting, buying and selling strategies in the study area.

\section{Producers' price setting strategy}

According to the survey result, about $48 \%$ of sample respondent farmers reported that they put their produce in homes of their relatives/friend traders on market place to be sold some other day other than the market day when the maize that offered to the market was not sold. Similarly $33.8 \%$ of sample respondent farmers reported that they took their product back to home and sold in another market day. The other $17.2 \%$ of sample respondents sold their product with the existing price. The remaining $1 \%$ took back home for own consumption. The survey further confirmed that, about $51.5 \%$ of sample respondents reported that market price was set through negotiation with traders and $26.2 \%$ respondents reported that price was set by the market. The remaining $19.7 \%$ and $2.6 \%$ of farmer respondents reported that the selling price of their produce was set by traders and themselves respectively. The majority of farmers identified that price was the major determining factor that affect their decision as to whom and which market to sell their produce. Hence, there existed absence of competitive pricing system, indicating the deviation of market from the competitive market norms.

The lack of modern postharvest handling practice and lack of facilitated storage facilities have required producers to sell the maize at prevailing prices. Knowing this, traders put pressure on producers to sell at low price. During marketing, every farmer sells their products on individual basis. This affected their bargaining power during the sale of maize.

The assessment has highlighted that, mostly May to September are months when prices of maize reaches highest (64.7\%), while December to January are months when price of maize are lowest (88.2\%). Due to seasonal nature of production, large volume of maize is supplied to the local market during harvesting seasons which decreases the bargaining power of producers. The rest depends on the market condition. According to the assessment 97.3 and 1.7 percent of maize producers sold their produces through cash in hand system and credit basis respectively, while the remaining is conducted through advance payment/early payment.

\section{Buying and selling strategy of traders}

Generally, grain trading is based on eye appraisal of the commodities and exchange takes place on bargaining. The strategies of traders in maximizing profit and develop bargaining power include the use of regular partner, long term relation with clients or suppliers, the use of intermediaries, trading with personalized network, availability of market information and its impact on price, feasibility of alternative market outlets and price setting practices.

About $88.2 \%$ of sample traders indicated that buying price was set by the market. But $8.8 \%$ of them are setting prices by traders themselves. The rest 3\% set by discussion with other traders. Most of the time wholesalers buy $70 \%$ of maize from Shahura (on their clients) and 30\% from village market. The reason to stay more in that area was due to high supply and better quality of maize than other markets.

On the other hand, the survey result revealed that about $64.7 \%$ of traders responded that selling price was set by negotiation with buyers of the product they offered. While the rest $20.6 \%$ and $14.7 \%$ of the respondents said that selling price was set by buyer and the market respectively. Moreover, about $83 \%$ and $17 \%$ of sample traders consider supply and demand and nearby market prices to determine the purchasing and selling price of the market respectively.

Traders used different marketing agents to sell their product in the market. Based on the survey result about $70.8 \%$ of sample traders reported that they personally in charged to sale. Whereas $10.6 \%$ and $4.6 \%$ of traders used 
the service of their family member and brokers at time of sale respectively. The rest $14 \%$ of traders sold their product through combination of themselves with brokers.

With regard to the payment mode, the survey result showed that about 53\% of sample traders (more of wholesalers) sold their product on cash and credit. Around $35.2 \%$ of traders particularly of farmer traders and retailers sold their product through cash only. Few of the traders $5.6 \%$ sold through credit. And the remaining $6.2 \%$ of sample respondents sold their product through combination of cash, advanced payment and credit.

The maize traders have used different methods to approach their clients. According to the assessment 58.8 and 35.2 percent of traders attracted their suppliers by fair scaling weighing and by giving better price than others, respectively. Similarly, offering credit service, giving pre-payment and using relatives and friends are the approaches often used by traders to attract their suppliers with a value of $2.5,2$ and 1.5 percent respectively.

3.2.3. Marketing channels and performance analysis

\section{Marketing channels of maize}

Marketing channel analysis describes the direction and volume of goods and services flow from producers to consumers which is intended to provide a systematic knowledge of the flow of goods and services from their origin to the final consumers. Maize marketing channels were analyzed based on their direction and volume of flow. Eight maize market channels were identified that pass the commodity from producers to consumers based on the data collected from different sources. The major actors in the channels were producers, rural assemblers, wholesalers, urban assemblers, retailers and consumers. The total quantity of maize produced by sample farmers was about 3,569.5 quintals; out of this the total quantity supplied to the market was 1,369 quintals were passed from producers to consumers.

There were six alternative buyers that purchased maize directly from sample households. From the marketed supply, 602.36 quintals or $44 \%$ was purchased by wholesalers directly from producers. $3 \%$ by cooperatives, $36.35 \%$ by rural assemblers, $4.45 \%$ by urban assemblers, $10.7 \%$ by retailers and $1.5 \%$ by consumers. The rural assemblers sold $75 \%$ to wholesalers, $23 \%$ to retailers and $2 \%$ to consumers (figure 1 ).

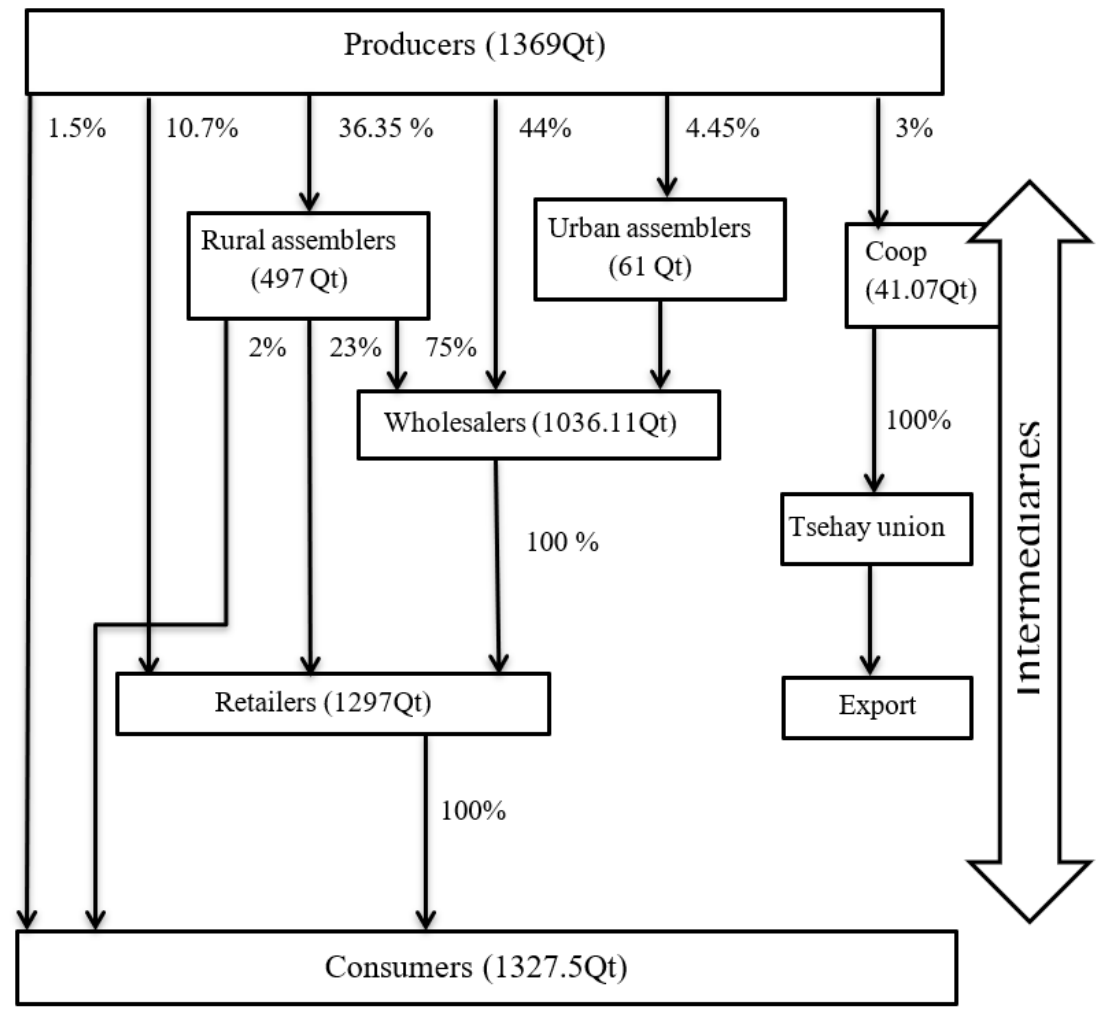

Source: Survey result (2017)

Figure 1: Maize market channels in the study area

The channel comparison was made based on volume that passed through each channel. The largest volume flowed through channel VI which was 602.36 quintals and the smallest flow was through channel III (9.94 quintals). The market channels were described as follow:

I. Producers $\rightarrow$ Consumers $(20.54 Q t)$ or $(1.5 \%)$

II. Producers $\rightarrow$ Retailers $\rightarrow$ Consumers (146.48Qt) or $(10.7 \%)$

III. Producers $\rightarrow$ Rural assemblers $\rightarrow$ Consumers $(9.94 Q t)$ or $(0.73 \%)$

IV. Producers $\rightarrow$ Rural assemblers $\rightarrow$ Retailers $\rightarrow$ Consumers $(114.31 \mathrm{Qt})$ or $(8.35 \%)$

V. Producers $\rightarrow$ Rural assemblers $\rightarrow$ Wholesaler $\rightarrow$ Retailers $\rightarrow$ Consumers $(372.75$ Qt $) /(27.23 \%)$ 
VI. Producers $\rightarrow$ Wholesaler $\rightarrow$ Retailers $\rightarrow$ Consumers (602.36Qt) or (44\%)

VII. Producers $\rightarrow$ Urban assemblers $\rightarrow$ Wholesaler $\rightarrow$ Retailers $\rightarrow$ Consumers (61Qt/ $(4.45 \%)$

VIII. Producers $\rightarrow$ Cooperatives $\rightarrow$ Tsehay union $\rightarrow$ Export (41.07Qt) or (3\%)

\section{Maize market performance}

Marketing performance of maize was analyzed by estimating the marketing margin, by taking into account associated average marketing costs for key marketing channels. The marketing margin refers to the difference between prices at different levels in the marketing system. The analysis of marketing channels was intended to provide a systematic knowledge of the flow of goods and services from its origin of production to final destination (ultimate consumers). Marketing margin used to measure the share of the final selling price that is captured by a particular actor in the market chain. Actors incurred marketing costs for transportation, storage cost (like rent, pest/rodent control and weight loss), sorting, packing, cleaning, loading, seller searching, commission fee, taxes and others. Production costs such as seeds, fertilizers, plant protection chemicals, land, labour and oxen were computed. As most of households used their own family labour, oxen and land, opportunity costs were used to compute costs of production. Accordingly, average cost of maize production for a sample household was 248 ETB/qt. When the product flows from producers to consumers, market agents' incur costs. The result showed that rural assemblers add more costs (ETB 46.9 per quintal) than other actors. Based on production costs and purchasing prices of the major market participants along the chain, margins were computed for producers, rural assemblers, wholesalers and urban retailers.

In the chain, producers had the highest percent share of market margin (52.32\%) and profit margin $(75.7 \%)$. From traders, rural assemblers had $19.1 \%$ and $11.37 \%$ share of market margin and profit margin, respectively (Table 6 below).

Table 6: Marketing margin and gross profit of actors in maize market chain.

\begin{tabular}{lllll}
\hline Cost items (ETB/qt) & Producers & Rural assemblers & Wholesalers & Retailers \\
\hline Purchasing price & 0 & 440 & 510 & 558 \\
Production cost & 248 & 0 & 0 & 0 \\
Marketing costs & & & & 15.25 \\
Transportation cost & 6.5 & 15.25 & 20.45 & 5.76 \\
Storage cost & 25.45 & 10.33 & 2.75 & 10.79 \\
Cleaning/packing & 0 & 7.35 & 5.2 & 1.57 \\
Commission fee/ Cost for brokers & 0 & 0.55 & 4.25 & 0.5 \\
Employees salary & 0 & 0.25 & 2 & 1.57 \\
Taxes/custom fee & 2 & 1.65 & 1.82 & 3.15 \\
Loading/unloading & 0 & 4.5 & 2.5 & 0.53 \\
Other costs & 4.25 & 7.02 & 0.65 & 39.12 \\
Total marketing cost & 38.2 & 46.9 & 39.62 & 597.12 \\
Total cost & 286.2 & 486.9 & 549.62 & 615 \\
Selling price & 440 & 510 & 558 & 57 \\
Market margin & 192 & 70 & 48 & 15.53 \\
\% share of margin & 52.32 & 19.1 & 8.38 & 17.88 \\
Profit margin & 153.8 & 23.1 & 4.12 & 8.8 \\
\% share of profit & 75.7 & 11.37 & & \\
\hline Source: Survey result & & & & \\
\hline
\end{tabular}

Source: Survey result (2017).

More marketing cost was added to transportation, storage and cleaning/packing. Actors in the market chain incurred $35.06 \%$ of marketing costs for transportation, $27.03 \%$ for storage costs, $14.25 \%$ for cleaning/packing, $6.19 \%$ for loading/unloading, $4.29 \%$ for taxes/custom fee, $3.88 \%$ for commission fee/cost for brokers, $1.67 \%$ for employees' salary and the rest for traders' personal expenses such as transport, food, mobile card and other utilities. Storage costs were incurred for storage rent, control storage pest and rodents, and weight loss during stocking. Weight loss during cleaning was also considered as cost for traders (Figure 2). 


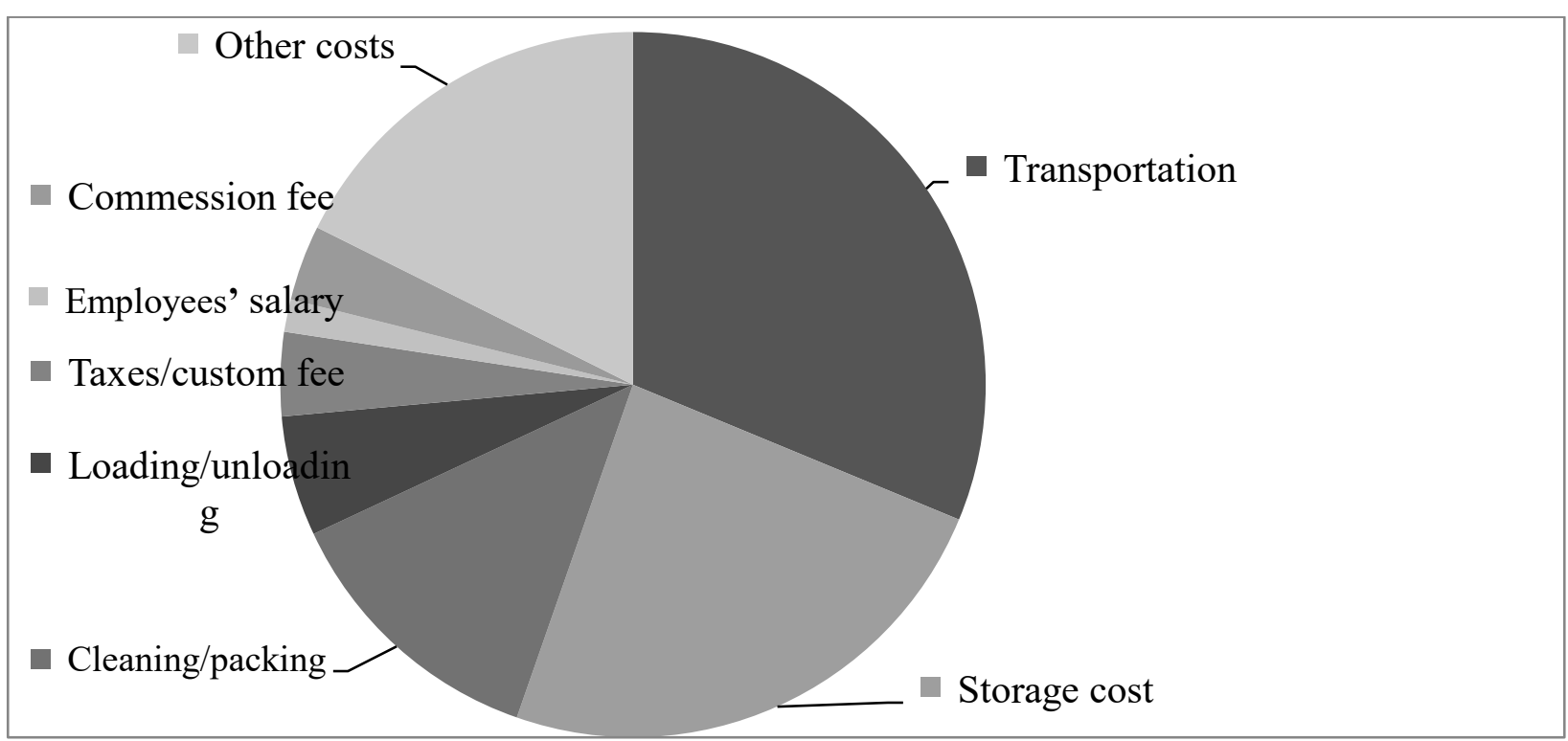

Source: Own sketch from 2017 survey data

Figure 2: Percentage share of maize marketing costs.

Table 7 explained marketing margin among different actors in different channels. Marketing margin is most commonly used to refer to the difference between producer prices of an equivalent quantity and quality of a commodity. However, it may also describe price differences between other points in the marketing chain, for example, between producer and wholesale, or wholesale and retail prices (Sarfraz, et al., 2008). A marketing margin is the percentage of the final weighted average selling price taken by each stage of the marketing chain. Total marketing margin is the difference between consumer pays and producer/farmer receives for his product. In other words, it is the difference between retail price and farm price (Cramers and Jensen, 1982).

Therefore, in this study, marketing margins were analyzed based on the average sale price of different marketing agents in the marketing channels of producers, rural assemblers, wholesalers, urban assemblers, cooperatives and retailers.

The result showed that total gross marketing margin was highest in channel $\mathrm{V}$ and it was $31.7 \%$ followed by both channel II and VII which accounted for $28.45 \%$ and $25.2 \%$ of Total Gross Marketing Margin (TGMM) added to maize price in the channel when it reached to the final consumers. From all maize actors, producers and urban assemblers have got the highest and lowest gross marketing margin which is accounted for $88.71 \%$ and $8 \%$ in channel VIII and VII respectively (Table 7 below).

Table 7: Percentage of marketing margin for different marketing channels.

\begin{tabular}{lllllllll}
\hline Marketing margin & \multicolumn{10}{c}{ Marketing channels } \\
\cline { 2 - 9 } & I & II & III & IV & V & VI & VII & VIII \\
TGMM & -- & 28.45 & 13.73 & 26.83 & 31.7 & 18.69 & 25.2 & 11.29 \\
GMMp & -- & 71.55 & 86.27 & 73.17 & 68.3 & 81.31 & 74.8 & 88.71 \\
GMMra & -- & --- & 13.73 & 11.76 & 17.65 & -- & --- & ---- \\
GMMw & -- & --- & --- & --- & 8.6 & 10.39 & 10.39 & --- \\
GMMua & -- & ---- & ---- & --- & --- & --- & 8 & --- \\
GMMcoop & -- & --- & --- & ---- & --- & -- & --- & 11.29 \\
GMMr & -- & 28.45 & --- & 17.1 & 9.26 & 9.26 & 9.26 & --- \\
\hline
\end{tabular}

Source: Survey result (2017). Note: GMMp, GMMra, GMMw, GMMua, GMMcoop, and GMMr means gross marketing margin for producers, rural assemblers, wholesalers, urban assemblers, cooperatives, and retailers respectively.

\subsection{Constraints and opportunities of maize market chain}

3.3.1. Production and marketing constraints of producers

According to the farm problems of sample households, improved seeds and fertilizers are the most important factors in production, which in turn influenced market supply of maize. These constraints adversely affect production and volume supplied to market. The major constraints of production and marketing in the study area were timely availability of inputs, prices of inputs and outputs, availability of credit, access to market information on market price, demand and supply, natural and environmental risk factors such as drought, flood, pest, disease and low soil fertility that farmers cannot grow maize without application of chemical fertilizers. Among these prices of fertilizers, timely availability of improved seeds, drought, pests/diseases of maize and availability of 
credit access were the most important constraints in the study area.

Higher fertilizer price and delayed delivery: Although application of fertilizer plays an important role for farmers to increase production and productivity, $17.17 \%$ of the respondents revealed that higher price of fertilizer forced farmers to use lower quantity of fertilizer. Beside this untimely delivery of fertilizer by cooperatives was also causing a serious challenge to the farmers. This in turn resulted in lowering yield and decreased the volume supplied to market. Thus, the higher price and untimely delivery requires due attention by the government.

Late arrival of inputs: Since agricultural products are seasonal all useful inputs need early arrangement to improve the production by applying inputs on the right time. But the survey result revealed that $12.62 \%$ and $6.06 \%$ of the producers complain delay in the supply of improved seeds and fertilizers respectively.

Drought/flood: Drought and flood are natural factors often beyond the control of farmers. According to the survey result $14.14 \%$ of the producers reported that drought as a constraint in production.

Pests/diseases: According to the survey result $15.65 \%$ of the producers revealed that storage pests (like rodent, weevil) as a marketing problem. Prevalence of disease was also one of the production problems encountered by farmers in the study area. Based on its occurrence, the most commonly occurred diseases were "stalk borer" (Ageda korkur) and rust for maize during production.

Lack of credit access: Although availability of credit is important source of cash for farmers to buy agricultural inputs, $9.59 \%$ and $5.55 \%$ of the respondents reported that lack of credit access to buy fertilizers and seeds respectively. Only few of the respondents accessed credit from formal sources. Due to this reason farmers were forced to use inputs below the recommended rate.

Labor shortage: Labor being a factor of production plays constructive role in increasing production and productivity of maize. As sample respondents reported that labor shortage was very crucial particularly during sowing, weeding, land preparation and threshing of crops. Thus, absence of sufficient labor force in the family made some farmers to hire additional labors and others form labor cooperation with neighbor farmers locally known as 'Webera'.

Table 8: Production and marketing constraints of maize producers.

\begin{tabular}{lll}
\hline Major constraints & $\mathrm{N}=198$ (yes) & $\%$ \\
\hline Price of fertilizers & 34 & 17.17 \\
Timely availability of improved seeds & 25 & 12.62 \\
Prices of improved seeds & 8 & 4.04 \\
Timely availability of fertilizers & 12 & 6.06 \\
Availability of credit to buy fertilizers & 19 & 9.59 \\
Availability of credit to buy seeds & 11 & 5.55 \\
Access to market information & 16 & 8.08 \\
Drought/flood & 28 & 14.14 \\
Pests/disease & 31 & 15.65 \\
Fertility of soil & 14 & 7.1 \\
\hline
\end{tabular}

Source: Survey result (2017).

3.3.2. Production and marketing opportunities of producers

Maize is considered as the main cash crop and food source for the farmers in many low lands and mid altitude zones of Ethiopia. This opportunity enabled farmers to produce this commodity for commercial purpose. Thus, these situations increased the production volume of maize in the area.

Improved maize seed varieties (such as BH-540, Shone and Limu), fertilizers and plant protection chemicals were distributed to farmers through cooperatives. Using these inputs with modern agronomic practices is a good opportunity for farmers to increase productivity. For example, in this case yield of maize increased from 10 quintal per hectare to 96 quintal per hectare and reduced cost of input transportation as they purchased from the nearby cooperatives. High productivity potential of the crop and suitable climatic conditions in the woreda are good opportunity of production for maize in the study area. Thus, maize is a dominant crop produced in the study area; due to this the average productivity of maize in the area was 34.37 quintals.

Farmer cooperatives: In addition to supplying agricultural inputs, cooperatives took part in grain trade. Accordingly, they purchased 41 quintals per year of maize from farmers as well as provided storage services for their members. This was good opportunity for farmers in stabilizing market price by competing with private traders. They could also be sources of reliable and current grain price information. However, it was not long lasting because they were constrained by financial capital. They could not accommodate the volume supplied to them.

3.3.3. Constraints and opportunities of traders

\section{Marketing constraints}

Table 9: indicates the major marketing constraints identified that hinder maize market were presence of unlicensed traders, unstable price, limited credit access, weak market information, low price of commodities at harvest time and non-transparent taxation. Among these, being not all traders were licensed was the main constraint of traders even though the law requires that a person should have a valid license to engage in grain trade, in reality there are 
too many people operating in the market without license. The unlicensed traders in the market affected the performance of market in creating unstable prices and reduce government income, which in turn affected development of market infrastructure.

Limited access to credit and non-transparent taxation system were the next important constraints and more than half of the respondents' also reported that unstable price and weak market information were the major marketing constraints.

Table 9: Marketing constraints of maize traders.

\begin{tabular}{lll}
\hline Major marketing constraints & $\mathrm{N}=34$ (yes) & $\%$ \\
\hline Not all traders are licensed & 28 & 82.35 \\
Limited access to credit & 26 & 76.47 \\
Weak market information & 17 & 50 \\
Prices are unstable & 19 & 55.88 \\
Absence of grades and standards & 5 & 14.7 \\
Multiple taxation & 6 & 17.65 \\
Non-transparent taxation system & 24 & 70.58 \\
Lack of demand for products & 13 & 38.24 \\
Absence of government support & 12 & 35.29 \\
to improve marketing & & \\
\hline Source: Survey result & &
\end{tabular}

Source: Survey result (2017), N= number of respondents.

\section{Marketing opportunities}

The major maize market opportunities pointed out by respondents were the presence of improved trends of quality of maize, and selling and purchasing prices, creating demand for other crops which are used for mixing with maize (finger millet, teff) and excess supply of maize in the study area.

Trends of product quality: Agricultural products quality determines the price and volume of supply. Table 10 indicated trends of maize quality in the market. Accordingly, 55.88\% of households reported that, generally, for the last five years, quality of maize showed increased a lot. Out of which $29.41 \%$ respondents considered a slightly increment of maize quality. One of the reasons for the increase in quality of maize was mainly the control of storage pests due to the provision of improved pesticides provided by cooperatives. Thus, increasing quality of maize attract all actors in the market chain.

Table 10: Trends of maize quality

\begin{tabular}{lll}
\hline Quality & $\mathrm{N}=34$ & $\%$ \\
\hline Increased a lot & 19 & 55.88 \\
Increased slightly & 10 & 29.41 \\
Same & 3 & 8.82 \\
Decreased slightly & 2 & 5.88 \\
\hline
\end{tabular}

Source: Survey result (2017), N= number of respondents

Trends of selling and purchasing prices: Recently, demand for maize is increasing as it is used to produce ethanol as biofuel, besides being a staple food in many countries and a feed for livestock in the form of forage, silage, or grain. At the same time, it increases the price of maize, which in turn has raised food prices in general. Table 11: Trends of maize selling and purchasing prices for the last five years.

\begin{tabular}{lllll}
\hline & Maize selling prices & \multicolumn{2}{l}{ Maize purchasing prices } \\
\hline Items & $\mathrm{N}=34$ & $\%$ & $\mathrm{~N}=34$ & $\%$ \\
\hline Increased a lot & 24 & 70.58 & 21 & 61.76 \\
Increased slightly & 7 & 20.58 & 9 & 26.47 \\
Same & 1 & 2.94 & 2 & 5.88 \\
Decreased slightly & 2 & 5.88 & 2 & 5.88 \\
\hline
\end{tabular}

Source: Survey result (2017), N= number of respondents

\section{CONCLUSIONS AND RECOMMENDATIONS}

\subsection{Conclusions}

Market chain analysis of the maize revealed that, the major alternative buyers that purchased maize directly from producers were rural assemblers, wholesalers, cooperatives, retailers, urban assemblers and consumers who are the main actors. Wholesalers were the main buyers of maize from farmers. The structure of the market was analyzed by taking the share of the four largest firms from the total supply of maize mobilized by the sampling traders per week during harvesting season in 2017. The four firms' concentration ratio (CR4) indicated that four largest traders handled $74.07 \%$ of the total volume of purchased maize. Suggesting that, the structure of the maize market in the study area was somewhat strong oligopoly feature.

The research result also indicated that existence of eight maize market channels in the study area. The flow 
of the commodities from Producers $\rightarrow$ wholesaler $\rightarrow$ retailers $\rightarrow$ consumers. High volume of maize passed through these actors from producers to consumers. The total gross marketing margin was highest in channel-V (Producers $\rightarrow$ rural assemblers $\rightarrow$ wholesaler $\rightarrow$ retailers $\rightarrow$ consumers) which was about $31.7 \%$ and lowest $11.29 \%$ in channel-VIII (Producers $\rightarrow$ Cooperatives $\rightarrow$ Sun union $\rightarrow$ Export). In the chain, Producers had the highest percentage share of market margin (52.32\%) and profit margin (75.7\%). From traders, rural assemblers had $19.1 \%$ and $11.37 \%$ share of market margin and profit margin, respectively.

Major constraints associated with production and marketing of maize producers were prices of fertilizers, timely availability of improved seeds, drought, pests/diseases of maize and availability of credit access were the most important constraints in the study area. As the price of input particularly price of fertilizers increased, farmers reduce the rate of fertilizers application below the recommended rate. As a result production and productivity decreased which result in less supplied to markets. In addition to these, there were major constraints associated with maize traders were large number of unlicensed traders in the market, limited access to credit, and nontransparent taxation system which adversely affected the performance of market.

The major opportunities in the maize market chains associated with input supply were cooperatives located in their kebeles. This helps in saving their time and reducing other costs related to purchasing inputs. As to production, a number of improved maize seeds and plant protection chemicals were available and supplied by cooperatives, which can increase productivity. The main source of market information for cooperatives was government department which is reliable and timely available. As the study areas have high maize production potential, it has the capacity to supply more volume to markets.

\subsection{Recommendations}

[1] The main costs of maize production were the costs incurred to purchase fertilizers. Moreover, the improved seed was not available at peak time of sowing when farmers required. Therefore, government should encourage farmers to strengthen the cooperative movements in order to be able to have access to a better mode of transport through mobilization of their resources. The costs of fertilizers can be reduced by using organic fertilizers and modern agronomic techniques such as crop rotation and intercropping which improve fertility of soil.

[2] Producers primarily accessed price and market information mainly from other farmers and/or grain traders. These might not be from primary and reliable sources. They sold their product with market prices that heard from their sources. On other hand, cooperatives mainly accessed the information from government marketing department/unions, which is accurate and from reliable source. Therefore, it needs to develop market information transferring system from cooperatives to farmers. This can be through posting current and updated price of crops regularly and create strong communication linkage with agricultural development agents and kebeles.

[3] Cooperatives purchased maize mainly at their store, which are located in farmers" "kebeles" or nearby kebele. They purchased relatively with better price than other traders that directly purchased from the farmers. However, it was not long lasting because they were constrained by financial capital. They could not accommodate the volume supplied to them. As a result, farmers sold to private traders with low price as compared to cooperatives purchasing prices. Therefore, it needs to improve financial strength of cooperatives by facilitating credit access in peak maize supply months.

[4] Since the maize market in the study area was oligopolistic, government should attract other traders to enter into maize trade by improving the existing credit system and giving different incentives in order to make the market more competitive.

[5] Existence of unlicensed traders in the maize market discouraged the legal traders to expand their business or enter into the market. Hence the trade and industry office of the woreda should take action to protect the legal traders from unfair competition with unlicensed traders either by convincing them to become legal or preventing informal traders not to participate.

\section{REFERENCES}

Baldwin, W. and Scott J. 2013. Market structure and technological change, Taylor and Francis.

Chamberlin J, Schmidt E (2012) Ethiopian agriculture: a dynamic geographic perspective. In: Food and agriculture in Ethiopia: progress and policy challenges, vol 74. University of Pennsylvania Press, Philadelphia, PA, p 21

Cramer G. L. and W. Jensen. 1982). Agricultural economics and agribusiness, 2nd Edition. McGraw Hill Book Company, USA. 250PP.

CSA (Central Statistical Agency). 2015a. Agricultural sample survey: time series data for national \& regional level (from 1995/96 (1988E.C)-2014/15 (2007 EC). Report on area and production of crops (private peasant holdings, meher season) Addis Ababa, Ethiopia

CSA (Central Statistical Agency). 2016. Statistical report on area and crop production. Addis Ababa, Ethiopia.

Emam A. A. 2011. Evaluating marketing efficiency of tomato in Khartoum State, Sudan. Journal of Agricultural Social Science. 7: 21-24.

FAO-AMIS. 2017. FAO Agricultural Market Information System. 
FAOSTAT 2012. http://Faostat.fao.org (accessed October 6, 2015)

Guush Berhane, John Hoddinott, Neha Kumar and Alemayehu Seyoum Tafesse 2011. The impact of Ethiopia's productive safety nets and household asset building programme: 2006-2010. Washington, DC: International Food Policy Research Institute.

Huffnagel HP (1961) Agriculture in Ethiopia. FAO, Rome.

Kalule S. W. and Kyanjo J. L. 2013. Marketing Margins and Efficiency of Cooking Banana Retail Trade in Kampala City, Uganda. International Journal of Sales and Marketing. 3: 9-18.

Kohls R. L. and Uhl N. 2002. Marketing of agricultural products, Prentice-Hall Inc.

OAWARD (Office of Alefa Woreda Agriculture and Rural Development). 2017. Annual report of the Woreda. Centeral Gondar Zone, Amhara Regional Sate, Ethiopia.

Onono J., Amimo J. and Rushton J. 2015. Constraints and efficiency of cattle marketing in semi arid pastoral system in Kenya. Tropical animal health and production. 47: 691-697.

Sarfraz Ahmad, Tahir Zahoor Chohan and Khurram Nawaz Saddozai. 2008. An Investigation into Cost and Revenue of Onion Production In Azad Jammu Kashmir, Journal of Agricultural Economics.

Tomek, W.G. and Kaiser, H.M. 2014. Agricultural Product Prices, 5th Edition. Cornell University Press, Ithaca, New York, USA

Wendmagegn Belete. 2014. Market Chain Analysis of Coffee in Dale District of Southern Ethiopia: M.Sc. Thesis Haramaya University, Ethiopia, 57P. 